\title{
Geographical Education in Primary School Curriculum in Turkey Between 1923-2018*
}

\author{
Nihal YILDIZ YILMAZ1 \\ Karamanoğlu Mehmetbey University, Karaman \\ TURKEY
}

\author{
Ali MEYDAN2 \\ Nevşehir Hacı Bektaş Veli University, Nevşehir \\ TURKEY
}

\begin{abstract}
${ }^{*}$ A portion of this research was presented in 1. International Congress on Geographical Education (UCEK/IGES-2018), 8-10 November 2018, Nevşehir-Turkey.

${ }^{1}$ Corresponding author: Dr., Karamanoğlu Mehmetbey University, Department of Elementary Education, Karaman, Turkey, nihalyildizyilmaz [at] gmail.com. ORCID: 0000-0002-6840-1594

2Prof. Dr., Nevşehir Hacı Bektaş Veli University, Department of Turkish Language and Social Sciences Education, Nevşehir, Turkey, alimeydan01[at] gmail.com ORCID: 000-0002-1278-096X
\end{abstract}

\begin{abstract}
This study aims to examine the change and transformation of geographical education in the Turkish primary school curriculum between 1923-2018. The research uses a qualitative document review method and a descriptive analysis process to analyse the data. Nine primary school programs created by the Ministry of National Education (MoNE) are identified as research documents. Dates of primary school curricula in Turkey between 1923-2018 are analyzed: 1924, $1926,1936,1948,1962,1968,1997,2005$ and 2018. The 1924 Boys' Primary School curriculum is a continuation of the pre-republic program and geographical education was included in Grades three, four and five under the name "Geography". The 1926 Primary School curriculum, and the 1936 Primary School curriculum, and the 1948 Primary School curriculum all include the name "Geography". The 1962 Primary School curriculum includes geographical education as "Society and Country Studies" and "Science and Nature" in Grades Four and Five. The lesson information in the 1968 Primary School curriculum and also in 1997, 2005 and 2018 show geographical education as "Social Studies", "Science (1968 and 1997), "Science and Technology" (2005) and "Science" (2018) for Grades Four and Five. From the 1926 Primary School curriculum to the 2018 Primary School curriculum, it is evident that geographical education occurs in Grades One, Two, and Three and Geography was included under the name of "life knowledge, which is a combination of Geography, History, Civics, Nature, and Science. It was determined the course hours differed from program. Purpose/objectives related to geographical education have gradually decreased. Given the importance of geographical education from the primary school level, achievements related to geography education can be increased.
\end{abstract}

\section{Keywords}

Geographical Education, Primary School Curriculum, Purpose / Objectives, Turkey 
Since the day of humanity's existence, the most important feeling in people has been the sense of curiosity. It is the desire to know or learn about the environment in which you live that triggers a sense of curiosity. For this reason, people have constantly tried to make sense of animals, plants and observing the sky. As a result of all this, the science of Geography emerged. Because Geography contains many branches of Science and is closely related to other branches of Science in different ways, different definitions have been made by scientists related to Geography. Erinç (2000) suggests Geography "Is a science that reveals the properties of places on earth and explores and explains the causes of similarities and separations between both these properties and various spaces and the laws that govern them"; while Özdemir (1997) defines Geography as "a synthesis science that establishes a chain of relations belonging to place". Doğanay (1998) describes Geography as "a science that studies natural, human and economic events on a geographical earth by establishing an interest in humans." Geography is not a single academic specialty. In an age when knowledge is divided into thousands of parts, Geography can remain in a very general context because the area of Geography is very wide. For example, geology, climatology, ecology, environmental science and a number of other human sciences evolved from Geography (Bonnet, 2008). Özçağlar (2000) defined Geography in accordance with those 4 basic principles. Geography is defined as a community of sciences that consists of applying various research methods and revealing the results obtained as a whole, depending on the basic principles of Geography, and contains many sciences in it.

Geography is a discipline that must be taught and learned from the point of view of the individual starting from their immediate environment; first recognizing their country, then the world, and then the universe in which they live- creating awareness at the point of transferring it from the past to the future. A person tries to recognize their house, then their street, neighborhood, district, province, country, world, and finally the universe in which they live. Respectively, this occurs starting from the birth of a person and until their death because as one gets to know each of these places, the sense of belonging will increase. Especially from primary school. As students are introduced to the environment, their country and increase their sense of belonging, they will work more and more eagerly for the development of these places in which they live.

Geographical education examines physical events occurring on Earth and the impact of these events on physical and human activities (Akınoglu, 2005). Pinar and Tuncer (2019) state that the main purpose of geographical education is to recognize the world spatially and to reveal the interaction between human and nature. Due to geographical education being under the name of Geography from high school, the aims of geographical education are clearly stated by the Ministry of National Education in the high school years. The MoNE (2018e: 10-11) secondary geography course (Grades 9, 10,11 and 12) explains the objectives of geographical education in the curriculum as follows: 
1. Conducting research using basic concepts, theories and research methods of geography science and reporting its results,

2. Achievement geographical skills within the framework of human-nature relationship,

3. Associating the basic elements of the universe with life,

4. Comprehend the functioning and change of natural and human systems,

5. Understanding spatial values belonging to his country and the world, starting from his immediate environment, and developing awareness of owning these values,

6. Achievement awareness of responsibility for the functioning of the ecosystem,

7. Understanding the importance of spatial planning for the harmonious coexistence and continuity of nature and human,

8. Developing "saving awareness" in the use of natural and human resources,

9. Make sense of the functioning of natural and human systems in local and global interaction,

10. Understanding the importance of harmonizing development processes with nature,

11. Evaluate natural disasters and environmental problems and develop applications for ways to protect and take precautions,

12. Understanding the role of environmental, cultural, political and economic organizations active at regional and global levels in international relations,

13. As a country of geographical accumulation and synthesis, Turkey understands the characteristics of its position in terms of regional and global relations and becomes aware of the potential that its country has,

14. Understanding the importance of having geographical information in achievement "Homeland consciousness,

15. According to Turkey's new vision, it has knowledge about developed and developing countries in the world, especially the regions and countries with close relations with Turkey."

Although geographical education seems to start in ninth grade for today's educational programs, it is the case that geographical subjects are included under different course names from the first grade of primary school. When the objectives of the secondary Geography course curriculum are examined, it is seen that each aim is included in different ways; they are more understandable and simplified expressions from the primary school programs. Apart from these, MoNE (2018e) secondary Geography program includes geographical skills in the curriculum (geographical observation, field work, geographic inquiry) whereas five (detection time, change and continuity detection, map skills, tables, graphs and diagrams to interpret, use evidence) MoNE (2018d) are located in the primary social studies curriculum.

Geography education is stated as a course that should be at all levels of education in terms of the individual's perception and recognition of the environment in which they live. This is because there is a close relationship between the individual's developmental characteristics and teaching principles, and their ability to perceive and understand space. As a matter of fact, Meydan (2017) has reconciled the ability to perceive and understand space with the principles of teaching. The ability to perceive and understand space begins with the birth of the child, and from primary school onwards, space features are given as part of the Life Sciences lessons. Teaching principles such as "close or away", "concrete to abstract", "known to unknown", "simple to complex" are given priority to the child's understanding of the phenomena and events that he sees and knows concretely in his immediate vicinity. 
Geography is one of the disciplines that establishes a relationship between the Social Sciences and Natural Sciences. Geography is defined as a discipline that bridges between Science and Social Sciences in line with natural and human processes due to the processing of topics related to Geography in Life Sciences, Science and Social Studies courses in the curriculum (Kızılçaoğlu, 2006).

In each updated program in Turkey, some studies related to geography education have been carried out and various changes have been made over time. The reason for these changes can be stated as adapting to the constantly renewed world order in the broadest sense. Since the establishment of the Republic in Turkey to the present day (1923-2020), many programs have been prepared and implemented in accordance with changing conditions. From the point of view of creating a theoretical basis for the study, the programs were considered with their main characteristics, and the draft programs were not included. These programs are listed as:

$\checkmark 1924$ Primary School Curriculum: The first program prepared after the establishment of the state of the Republic of Turkey and implemented in all primary schools.

$\checkmark 1926$ Primary School Curriculum: Its most important feature and innovation is that it brings the practice of collective teaching (Arslan,2000).

$\checkmark 1936$ Primary School Curriculum: The principles a child should follow throughout their entire school life, starting from the first day they arrive at school, have been determined in the form of articles and in a way that does not challenge any disagreement and interpretations. In this program, the principles required by national life are included in particular (Arslan, 2000).

$\checkmark 1948$ Primary School Curriculum: With a period of 20 years, it is the longest implemented primary school program in the history of the Republic of Turkey.

1968 Primary School Curriculum: Differs from past programs. In addition to the "purpose of Turkish National Education" set out in the National Education Council, it was determined that the purpose of primary education and the principles of primary education should also be included (Arslan, 2000).

$\checkmark 1998$ Primary School Curriculum: The 1998 primary school curriculum parallels the 1968 program. It was determined that the issues, principles and explanations were repeated, and that new purposes and principles were not included in accordance with the issues, principles and requirements of the age.

$\checkmark 2005$ Primary School Curriculum: This is based on constructivist educational foundations in which the student is passive, guiding the active teacher (Illhan Beyaztaş, Kaptı, and Senemoğlu, 2013).

$\checkmark 2018$ Primary School Curriculum: Two areas have been emphasized. The first is the transition to the information society and the human qualities required by the information society; and the second is that acquiring these qualities depends on the concept of "lifelong learning" (Daşcan,2018).

Students' knowledge of what a place looks like is extremely important in providing the opportunity to improve their level of perception of their living environment. Instead of memorizing place names for a qualified geographical education, the process of obtaining knowledge is based on the truth about 
Geography so they can use it and it will be more effective. Especially in primary school, the geographical features of our country and basic geographical information are transferred to students (Kızlçaoğlu, 2006). At this point, the importance of Geography education in primary school is revealed. Primary school is the level of education in which students are given basic information about almost every subject. Learning general and private information (such as geopolitical and strajegic location) about our country from an early age will mean educating individuals who can generate ideas and make predictions on issues related to the country in the future. For this reason, it is important that geographical information about the world and our country be given to students from primary school. While geography education is so important at all levels of education from primary school, when the literature is examined, it is seen that studies related to geographical education are mainly carried out at the level of Secondary Education and above. Geographical education studies conducted for primary schools are quite small. For this reason, it is aimed to close a gap that exists in the literature with this research. The purpose of the research is to examine the change and transformation of Geography education in the primary school programs prepared from the republican period to the present day. For this purpose, answers to the following questions will be sought:

1. What are the courses, course hours and purposes/objectives related to geographical education included in the courses in the 1924 primary school curriculum?

2. What are the courses, course hours and purposes/objectives related to geographical education included in the courses in the 1926 primary school curriculum?

3. What are the courses, course hours and purposes/objectives related to geographical education included in the courses in the 1936 primary school curriculum?

4. What are the courses, course hours and purposes/objectives related to geographical education included in the courses in the 1948 primary school curriculum?

5. What are the courses, course hours and purposes/objectives related to geographical education included in the courses in the 1968 primary school curriculum?

6. What are the courses, course hours and purposes/objectives related to geographical education included in the courses in the 1998 primary school curriculum?

7. What are the courses, course hours and purposes/objectives related to geographical education included in the courses in the 2005 primary school curriculum?

8. What are the courses, course hours and purposes/objectives related to geographical education included in the courses in the 2018 primary school curriculum? 


\section{Methodology}

\section{Research Design}

In this research, a document review method from qualitative research methods was used. Document review is one of the most effective methods that requires a short time and involves selecting the necessary information instead of collecting information. However, one of the important points here should be to avoid biased selectivity (Bowen, 2009). The following steps were applied when using the document review method in the research:

1. Accessing documents,

2. Checking authenticity,

3. Understanding documents,

4. Data analysis,

5. Using data (Yıldırım and Şimșek, 2018).

\section{Source of Data}

Nine primary school programs from the Republic-era to the present, created by the Ministry of National Education (MoNE), constitute the research documents. These documents are: 1924 primary school curriculum, 1926 primary school curriculum, 1936 primary school curriculum, 1948 primary school curriculum, 1962 primary school curriculum, 1968 primary school curriculum, 1997 primary school curriculum, 2005 primary school curriculum and 2018 primary school curriculum.

\section{Data Collection}

Data from the study was obtained through document review. Document review is a data source in which existing records or documents are systematically examined. The basic requirement of a successful document review is to find and examine the documents related to the subject and create the necessary arrangements for a synthesis to occur that will reveal certain situations or opinions. (Karasar, 2011; Yıldırım \& Şimșek, 2018). The curricular programs of the Ministry of National Education in primary schools for 1924 and 1926 publications are used, together with publications of the Ministry of Culture for primary school curriculums, in1936, 1948. In 1968 the primary school curriculums of the Ministry of National Education publications is used together with 1998 primary curriculum publications, 2005, publications of the Ministry of Education and their primary school programs from 2018 primary curriculum.

\section{Data Analysis}

Descriptive analysis was used in the analysis of the data in accordance with subproblems. Descriptive analysis is a method of analysis in which data is shown, described and examined as is, and there is no detailed and fictional analysis (Sönmez \& Alacapinar, 2016). Data is summarized and interpreted according to previously 
determined themes (Yıldırım \& Şimşek, 2018). In the study, it was determined which courses may be related to Geography by examining the weekly course distribution charts of the programs. After that, the general purposes/objectives of these courses were examined and analyzed, determining which ones may be related to Geography. However, in the 1924 first school curriculum, it is seen that the purposes of geographical education are considered in the form of subject integrity. Therefore, in the 1924 first school curriculum, geographical education was considered as the integrity of the subject.

\section{Validity and Reliability of Research}

In order to ensure the internal validity of the research, it is necessary to determine the suitability of the terms mentioned in the research for the content and whether the content and findings are consistent. In ensuring external validity, it is not important that the sample represents the research universe, but it is important that the sample is suitable for the event to be investigated (Maxwell, 1992). In order to ensure the internal validity of the research, the relationship of the general purposes/objectives obtained from the programs with Geography education was revealed and interpreted. In order to ensure external validity, all programs from the Republic-era to the present day have been examined and the method of the research, the universe, all the processes in the process of data collection and vereirn analysis have been described in detail.

In order to ensure the reliability of qualitative studies, it is important to receive feedback by sharing with experts in the field. As a matter of fact, Roberts and Priest (2006) stated that reliability can be increased by sending data about the analyses and findings to an independent researcher and receiving feedback. Objectives/objectives of the curricula obtained in the study were sent to an independent researcher specializing in the field of Geography education and purposes/objectives were asked to be associated. The associations of the researchers and the associations of the field specialist were $100 \%$ overlapping.

\section{Findings}

The results of the programs were presented together with tables in accordance with the sub-problems.

\section{Geographical Education in The Primary School Curriculum of 1924}

In Table 1, the general objectives of the courses related to geography education in the 1924 curriculum are examined: The Nature, Agriculture, Hygiene courses (1 hour each), 4 and 5 hours for the first 2 classes for the class, it is seen as a direct geography lesson ( 1 hour in third grade, 2 hours each in fourth and fifth grade). 
Table 1

1924 Primary School Program Weekly Course Distribution Chart (Ministry of Education, 1924, P.3)

\begin{tabular}{|c|c|c|c|c|c|c|}
\hline \multicolumn{2}{|l|}{ Lessons } & 1. grade & $\begin{array}{l}2 . \\
\text { grade }\end{array}$ & $\begin{array}{l}3 . \\
\text { grade }\end{array}$ & $\begin{array}{l}4 . \\
\text { grade }\end{array}$ & $\begin{array}{l}5 . \\
\text { grade }\end{array}$ \\
\hline \multirow[t]{6}{*}{ Turkish } & & & & & & - \\
\hline & Quran Alphabet & 12 & - & - & - & 2 \\
\hline & Recitation & - & 4 & 3 & 2 & 1 \\
\hline & Spelling & - & 2 & 2 & 1 & 2 \\
\hline & Essay & - & 1 & - & 2 & 1 \\
\hline & & Grammar & - & - & - & 1 \\
\hline \multicolumn{2}{|c|}{ Quran and Religious Courses } & - & 2 & 2 & 2 & 2 \\
\hline \multicolumn{2}{|c|}{ History } & - & - & 1 & 2 & 2 \\
\hline \multicolumn{2}{|c|}{ Geography } & - & - & 1 & 2 & 2 \\
\hline \multicolumn{2}{|c|}{ Study of the Nature, Agriculture, Hygiene } & 3 & 3 & 2 & 2 & 2 \\
\hline \multicolumn{2}{|c|}{ Ethics and Citizenship information } & 1 & 1 & 1 & 1 & 1 \\
\hline \multicolumn{2}{|c|}{ Painting } & 2 & 2 & 2 & 2 & 2 \\
\hline \multicolumn{2}{|l|}{ Music } & 2 & 2 & 2 & 1 & 1 \\
\hline
\end{tabular}

Among the courses included in the 1924 primary school curriculum, the nature analysis, agriculture and hygiene lesson and the basic knowledge of geography education (similar to today's Life Science course) were given in 1st and 2 nd grade. However, the objectives of nature studies, agriculture and hygiene courses were not specified in this program. It is seen that in the 1924 Primary School Curriculum, the geography course was targeted as a subject integrity;

$\checkmark$ The location of the school is divided into local geography

$\checkmark$ Teaching children the commercial activities of that region, rather than just giving children geographical information

$\checkmark$ Class plan, school plan, neighborhood plan, Village Plan, city plan

$\checkmark$ Map Knowledge

$\checkmark$ Direction information

$\checkmark$ Natural phenomena

$\checkmark$ Wind, rain, snow, tide, currents, volcano, earthquake

$\checkmark$ Turkey's borders; rivers, seas, climate

$\checkmark$ Animal World

$\checkmark$ Product

$\checkmark$ Population

$\checkmark$ Local governments

$\checkmark$ Industry

$\checkmark$ Trade

$\checkmark$ Most important commercial centers

$\checkmark$ Transport

$\checkmark$ Presentation for delegation

$\checkmark$ Shape and Structure of the Earth, Poles

$\checkmark$ Seasons

$\checkmark$ Regions

$\checkmark$ People living in hot and cold climates, agriculture and farming

$\checkmark$ Continents

$\checkmark$ Countries

$\checkmark$ Countries of interest to Turkey

$\checkmark$ Economic relations of Turkey" (Ministry of Education, 1924, p.28).

When the general aimed of the above Geography course are examined, it is seen that the sections related to the Geography course are considered as subject integrity. 
The location of these schools, with their geographic location and activities with the economic activities of the surrounding cities, maps, plans and directions, events, Turkey's geographical features, creatures, plants, population, industry, commerce, climate, the poles, the movements of the earth, continents, and the impact on the people of Turkey- nearly every issue is related to Geography. As such, relations with other countries are stated in a holistic manner.

\section{Geographical Education in the Primary School Curriculum 1926}

When the objectives of the courses in Table 2 are examined, it is seen that the courses containing the subjects related to geography education are Life Science, Geography and Nature courses. Life Science class is 4 hours in the first 3 classes, while 4 and 5. it is not included in the classes, and the Geography lesson is 3 hours although not included in Grades 4 and 5. There are 2 hours in class, and Nature lessons in Grades 4 and 5 are set as 2 hours each.

Table 2

1926 Primary School Program Weekly Course Distribution Chart (Ministry of Education, 1926, P.1)

\begin{tabular}{|c|c|c|c|c|c|c|}
\hline \multicolumn{2}{|l|}{ Lessons } & 1. Grade & $\begin{array}{c}2 . \\
\text { Grade }\end{array}$ & $\begin{array}{c}3 . \\
\text { Grade }\end{array}$ & $\begin{array}{c}4 . \\
\text { Grade }\end{array}$ & $\begin{array}{c}5 . \\
\text { Grade }\end{array}$ \\
\hline \multirow[t]{7}{*}{ Turkish } & & & & & & - \\
\hline & Quran Alphabet & 10 & - & - & - & 3 \\
\hline & Reading & - & 4 & 4 & 3 & 1 \\
\hline & Spelling & - & 2 & 2 & 2 & 2 \\
\hline & Essay & - & 1 & - & 2 & 1 \\
\hline & Grammar & - & - & - & 1 & 1 \\
\hline & & Handwriting & - & 2 & 2 & 1 \\
\hline \multicolumn{2}{|c|}{ Religious Education } & - & 3 & 2 & 1 & 1 \\
\hline \multicolumn{2}{|c|}{ Life Science } & 4 & 4 & 4 & - & - \\
\hline \multicolumn{2}{|c|}{ Math } & 4 & 4 & 5 & 5 & 5 \\
\hline \multicolumn{2}{|c|}{ History } & - & - & - & 2 & 2 \\
\hline \multicolumn{2}{|c|}{ Geography } & - & - & - & 2 & 2 \\
\hline \multicolumn{2}{|c|}{ Nature lessons } & - & - & - & 2 & 2 \\
\hline \multicolumn{2}{|c|}{ Items } & - & - & - & - & 2 \\
\hline \multicolumn{2}{|c|}{ Citizenship information } & - & - & - & 2 & 1 \\
\hline \multicolumn{2}{|c|}{ Painting- Handmade } & 4 & 4 & 4 & 2 & 2 \\
\hline \multicolumn{2}{|c|}{ Music } & 2 & 2 & 1 & 1 & 1 \\
\hline
\end{tabular}

The Life Science course includes both the subjects of the Social Sciences and the subjects of the Sciences and therefore includes the subjects related to geographical education. When the purposes of the courses were examined, it was determined that the nature courses also contained purposes related to geographical education.

The aimed shown for the Geography course in the 1926 curriculum of the first schools include: When examining the general objectives of the Geography course, students introduce their country and endearing the country to introduce citizens living in other parts of the world, with the characteristics of geographic events to learn, get to know other people, always observe events to occur has been identified as the common 4 on the purposes (Ministry of Education,1926, p.71). 
When the purposes of the Life Science course were examined in the program, it was determined that only 2 purposes were related to Geography education. These purposes consist of recognizing the geographical environment in which it lives, mastering the geographical events around it, determining the effects of the natural environment on humans and the effects of humans on nature (Ministry of Education, 1926, p.7-8)

In addition, in the 1926 primary school curriculum, subjects related to geographical education were also given in natural knowledge classes. The general purposes of the natural knowledge course related to geography education are as follows:

When the purposes of natural knowledge courses were examined in the program, it was determined that three purposes were related to geographical education. In these, it is to examine the child's natural environment, to tell the child about the mutual interactions of people and nature, and to make the child love nature (Ministry of Education. 1926, p.72).

\section{Geographical Education in the Primary School Curriculum of 1936}

Table 3 is examined and it is determined that the courses containing the subjects related to geographical education are life knowledge, geography, dormitory knowledge and nature knowledge. In Grades 1, 2 and 3 by increasing the duration of the Life Science course there are classes of 5, 6 and 7 hours in that order; Geography lesson occur again Grades 4 and 5 with 2 hours in classes; Dormitory information Grades 4 and 5 with 2, 1 hour in order; the Natural knowledge lesson is again in Grades 4 and 5 and the classes are set as 3 hours each. Dormitory knowledge courses and natural knowledge courses have been studied because they include geographical education topics.

Table 3

1936 Primary School Program Weekly Course Distribution Chart (The Ministry of Culture, 1936, p.5)

\begin{tabular}{|c|c|c|c|c|c|}
\hline \multirow[t]{2}{*}{ Lessons } & \multicolumn{3}{|c|}{ I. Term } & \multicolumn{2}{|r|}{ II. Term } \\
\hline & 1. grade & 2. grade & 3. grade & 4. grade & 5. grade \\
\hline Turkish & 10 & 7 & 7 & 6 & 6 \\
\hline History & - & - & - & 2 & 2 \\
\hline Geography & - & - & - & 2 & 2 \\
\hline Citizenship information & - & - & - & 2 & 1 \\
\hline Nature Lessons & - & - & - & 3 & 3 \\
\hline Family information & - & - & - & 2 & 2 \\
\hline Life Science & 5 & 6 & 7 & - & - \\
\hline Math & 4 & 4 & 4 & 4 & 5 \\
\hline Painting & 4 & 4 & 4 & 2 & 2 \\
\hline Writing & - & 2 & 1 & 1 & 1 \\
\hline Music & 1 & 1 & 1 & 1 & 1 \\
\hline Physical Education & 2 & 2 & 2 & 1 & 1 \\
\hline
\end{tabular}

In the program, some developments have been made in line with the principle of collective teaching, with special attention to the development characteristics of primary school students. Although the principles of collective teaching were adopted, towards the end of the third grade, it was requested that the "life science" course be divided into groups and branches in order to increase the students ' ability 
to study events and objects according to scientific rules. In the primary school curriculum, the purpose of the Geography course is determined as follows:

The purposes of the Geography course are examined: There are 5 purposes that consist of introducing the country to students, providing information about economic activities, characteristics of the world and geographical events, introducing countries in which the given country has a close relationship, questioning the geographical events it experiences, informing about maps (the Ministry of Culture, 1936, p.92).

In the 1936 primary school curriculum, the geographical education course is 4 hours, as shown in Table 3 and it starts from Grade. 4. In Grades 1, 2 and 3 the basic information about geographical education is given in the Life Science course. General purposes associated with geographical education for the Life Science course are as follows:

$$
\begin{aligned}
& \checkmark \text { "...Examine the child's environment and living conditions in terms of } \\
& \text { geography; ... } \\
& \checkmark \text { Popularizing the beauties of nature..." (the Ministry of Culture, 1936, p.134). }
\end{aligned}
$$

In the program, it was determined that the two purposes of the Life Science course are related to geographical education. These purposes consist of studying the child's environment in terms of Geography and popularizing nature.

In the 1936 Primary School Curriculum, subjects related to geographical education were also given in natural knowledge classes. The general purposes of the natural knowledge course related to geographical education are as follows:

The purposes of three the natural knowledge course in the program are associated with geographical education. These consist of examining the natural events around the child, teaching the interaction of human and nature and popularizing nature (the Ministry of Culture, 1936, p.113-114).

\section{Geographical Education in the Primary School Curriculum of 1948}

In Table 4, it is determined that the courses containing the subjects related to geographical education are Life Science, Geography and Nature Lessons. The duration of the Life Science course remains the same for Grades 1, 2 and 3 with classes of 5, 6 and 7 hours respectively. The duration of the Geography course remains the same for Grades 4 and 5 at 2 hours each, and the Nature Lessons for Grades 4 and 5 are classes of 3 hours each.

\begin{tabular}{|c|c|c|c|c|c|}
\hline \multirow[t]{2}{*}{ Lessons } & \multicolumn{3}{|c|}{ I. Term } & \multicolumn{2}{|r|}{ II. Term } \\
\hline & 1. grade & 2. grade & 3. grade & 4. grade & 5. grade \\
\hline Life Science & 5 & 6 & 7 & - & - \\
\hline Turkish & 10 & 10 & 7 & 6 & 6 \\
\hline History & - & - & - & 2 & 2 \\
\hline Geography & - & - & - & 2 & 2 \\
\hline $\begin{array}{l}\text { Citizenship } \\
\text { information }\end{array}$ & - & - & - & 2 & 1 \\
\hline Nature Lessons & - & - & - & 3 & 3 \\
\hline
\end{tabular}

Table 4

1948 Primary School Program Weekly Course Distribution Chart (MoNE,1948, p.24) 


\begin{tabular}{llllll}
\hline Math & 4 & 4 & 5 & 4 & 4 \\
\hline Family information & - & - & - & 2 & 2 \\
\hline Painting & 4 & 4 & 4 & 2 & 2 \\
\hline Writing & - & 2 & 1 & 1 & 1 \\
\hline Music & 1 & 1 & 1 & 1 & 1 \\
\hline Physical Education & 2 & 2 & 2 & 1 & 1
\end{tabular}

It has been studied because the subjects of the Natural Science course are included in the Nature Sciences and therefore include geographical education. The 1948 Primary School Curriculum is the longest running program with a duration of 20 years. Geographical education is the last program in existence under the name of Geography. The general objectives of the Geography course according to the 1948 program are;

$\checkmark$ To introduce and popularize our country and compatriots to children.

$\checkmark$ To make students knowledgeable and effective elements in the economic development of the dormitory by examining the mutual effects of people with each other and their geographical environment, the ways of living and the ways of living of human communities.

$\checkmark$ The children of the world and its place in the solar system, and provide students with information about their actions and consequences and see them frequently in touch to find relationships between events and causes of events and the geography accustom commitment.

$\checkmark$ Introduce children to other countries and nations of the world with the countries that have the most relations with our country.

$\checkmark$ Giving students the idea of a map is to make them understand and benefit from the map." (MoNE, 1948, p.139).

There are five objectives of the Geography course in the program. These purposes consist of introducing students to the country, providing information about economic activities, characteristics of the world and geographical events, introducing countries with which the country has close relations, questioning the geographical events it experiences, and informing them about maps.

In the 1948 Primary School Curriculum, the geographical education course is 4 hours, as shown in Table 4; it starts from Grade 4. In Grades 1, 2 and 3, basic information about geography education is given in the Life Science course. General objectives of the Life Science course are as follows:

$\checkmark \quad$ "...To give them knowledge that will allow them to correctly interpret everyday natural events, love for the beauty of nature and good habits for the protection of nature elements;

$\checkmark$ “... Have the child review his environment and living conditions in terms of geography.

$\checkmark$ Gradually observe and study everyday events related to nature and social life, with the help of general concepts that will eventually be reached, to prepare children for an opinion and examination in accordance with other branches of science." (MoNE, 1948, p.40-41).

Three of the general purposes of the Life Science course in the program are associated with geographical education. These consist of having necessary knowledge about nature and protecting nature, observing its environment from a geographical point of view, observing natural events.

In the 1948 Primary School Curriculum, subjects related to geography education were also given in natural knowledge classes. The general purposes of the natural 
knowledge course related to geographical education are as follows: Four of the general purposes of the Natural Knowledge course in the program are associated with geographical education. These consist of arousing curiosity about nature, showing the beauty of nature, understanding the relationship between living things, showing the natural beauty of the country (MoNE, 1948, p.153-154).

\section{Geographical Education in the Primary School Curriculum of 1968}

The 1968 Primary School Curriculum is the completed form of the 1962 Primary School draft program. Looking at Table 5, it is seen that the courses which include topics related to geographical education are Life Science, Science and Social Studies. The duration of Life Science course in Grades 1, 2 and 3 are 5 hours; the duration of Science courses in Grades 4 and 5 are 4 hours each; and the duration of the Social Studies course in Grades 4 and 5 are set at 3 hours each. In Table 5 of the 1968 Program, compared to earlier programs of the primary school years, it can be seen that History, Geography and Civics courses were collected in the 1948 program under the name of Social Studies, Natural Knowledge and Agriculture, and Science. When the course charts are examined, similar courses are encountered with later programs.

Table 5

1968 Primary School Program Weekly Course Distribution Chart (MoNE, 1968, P.269-299)

\begin{tabular}{lccccc}
\hline Lessons & 1.grade & 2. grade & 3.grade & 4. grade & 5.grade \\
\hline Turkish & 10 & 10 & 10 & 6 & 6 \\
\hline Math & 5 & 5 & 5 & 4 & 4 \\
\hline Science & - & - & - & 4 & 4 \\
\hline Social Studies & - & - & - & 3 & 3 \\
\hline Life Science & 5 & 5 & 5 & - & - \\
\hline Religious culture and ethics & - & - & - & 2 & 2 \\
\hline Painting & 1 & 1 & 1 & 2 & 2 \\
\hline Music & 1 & 1 & 1 & 1 & 1 \\
\hline Physical Education & 3 & 3 & 3 & 3 & 3 \\
\hline
\end{tabular}

The objectives of the Social Studies course in the 1968 primary school program are as follows:

* “....3. In terms of improving the ability to recognize the environment, homeland and the world:

a) Recognize their environment and homeland; gain general knowledge about Turkey's relations with near and far neighboring countries and nations of the world;

b) They achievement the necessary plan, sketch and map information and become able to benefit from them;

c) They become knowledgeable and effective citizens in the economic development of the country by studying the mutual effects of people with each other and their geographical environment, the ways of living and the ways of living of human communities;

d) Comprehend the effects of Science and technical developments on human life; have a love for explorers and scientists;

e) They learn to investigate the causes of geographical events that they often see and contact with, and to find and extract connections and relationships between these events..." (MoNE, 1968, p.64). 
One of the four general purposes set for the Social Studies course is associated with geographical education. These consist of knowing the country and having knowledge about other countries, having knowledge of plans, sketches and maps, mutual interactions of people and geographical circles, and understanding geographical events.

In the 1968 Primary School Curriculum, the geographical education course is 4 hours, as shown in Table 5 and it started from Grade 4. In Grades 1, 2 and 3 the basic information about geography education is given in the Life Science course. General objectives of geographical education in Life Science course are as follows:

$\checkmark$ "With this course, students develop their skills and skills related to recognizing the immediate environment;

- Understands and correctly interprets the natural events of the environment, determines the impact of these events on human life,

- Loves the environment and the natural beauty of the environment,

- They recognize the environment and try to find better ways to live by studying the possibilities of living in the environment,

- Achievement awareness of social development by studying daily events, items that they use every day, artifacts, monuments of the immediate environment..." (MoNE, 1968, p.39-40).

One general purpose of the Life Science course in the program is associated with geographical education. It consists of understanding natural events and loving the beauty of nature.

In the 1968 primary school program, the aims of geographical education in the science curriculum are as follows:

$\checkmark \quad$ "...Starting from the near environment, he / she becomes aware of the relationship between living and inanimate beings in the environment

$\checkmark \quad$ Know and discuss methods of protecting the environment and wildlife.

$\checkmark \quad$ Knows the need to protect and develop natural resources.

$\checkmark$ Knows that both individuals and society are responsible for protecting the environment and Wildlife

$\checkmark \quad$ Understands and describes how technological products and systems can be used to protect natural resources..." (MoNE, 1968, p.81).

The five objectives of the Science course in the program are associated with geographical education. These are the purposes of understanding the relationship between living and inanimate beings, protecting the environment, and protecting natural resources.

\section{Geographical Education in the Primary School Curriculum OF 1998}

With the 1998 primary education curriculum, compulsory education was introduced, which provides 8 years of primary education. In Table 6, it is seen that the courses which include topics related to geographical education are Life Science, Science and Social Studies. The duration of the Life Science course in Grades 1, 2 and 3 are 5 hours each; the duration of the Science course in Grades 4 and 5 are 3 hours 
Yıldız Yllmaz, N., Meydan, A. (2020). Geographical Education in Primary School Curriculum in...

each; the duration of the Social Studies course in Grades 4 and 5 are set as 3 hours each.

Table 6

1998 Primary School Program Weekly Course Distribution Chart (MoNE, 1998a)

\begin{tabular}{lccccc}
\hline Lessons & 1. grade & 2. grade & 3. grade & 4.grade & 5. grade \\
\hline Turkish & 12 & 12 & 12 & 6 & 6 \\
\hline Math & 4 & 4 & 4 & 4 & 4 \\
\hline Life Science & 5 & 5 & 5 & - & - \\
\hline Science & - & - & - & 3 & 3 \\
\hline Social Studies & - & - & - & 3 & 3 \\
\hline Foreign Language & - & - & - & 2 & 2 \\
\hline Religious culture and ethics & - & - & - & 2 & 2 \\
\hline Painting & 2 & 2 & 2 & 1 & 1 \\
\hline Music & 2 & 2 & 2 & 1 & 1 \\
\hline Physical Education & 2 & 2 & 2 & 2 & 2 \\
\hline Business Training & - & - & - & 3 & 3 \\
\hline Individual and collective event & 3 & 3 & 3 & - & - \\
\hline Optional lessons & - & - & - & 3 & 3 \\
\hline
\end{tabular}

The general purposes of the Life Science course in the 1998 Primary School Curriculum related to geographical education are as follows:

$\checkmark \quad$ “...Sensitivity to country and world events,

$\checkmark \quad$.... To be able to comprehend the effects of natural events,

$\checkmark \quad$.... Ability to protect the environment..." (MoNE, 1998b, p.13)

There are three purposes associated with geographical education in the Life Science program. These consist of sensitivity to country and world events, the effects of natural events, and the protection of the environment.

The Social Studies curriculum was prepared in 1998. In this program, the general objectives of the Social Studies course related to geographical education are as follows:

".... In terms of their ability to recognize the environment, homeland and the World

$\checkmark \quad$ 1. They understand the importance of our country's place in the world and develop their feelings of responsibility for the development of our country.

$\checkmark \quad$ 2. Achievement general knowledge about Turkey's relations with near and far neighboring countries and other countries of the world.

$\checkmark$ They learn the geographical features of other countries and regions where Turkish people live, they understand that the Turkish population are a great nation living in a large area.

3. It examines the mutual effects of people with each other and their geographical environment, the way human communities live and the way they live; they grow up as knowledgeable and effective citizens in the economic development of the country.

4. They achievement plan, sketch, map and graphic information and become able to benefit from them.

5. They understand the importance of environmental protection for today and for years to come.

6. Understand that a livable environment is a basic human right..." (MoNE, 1998c, p.538) 
One of the four general purposes in the Social Studies curriculum is associated with geographical education, and the seven sub-purposes below it are also associated. These include the geographical location of the country, the country's relations with other countries, the places where Turkish people live, the geographical environment human interaction, plan, sketch and map information, the importance of environmental protection.

In the Science course of the primary education program updated in 1998, the purposes associated with Geography are stated as follows:

“...8. Recognize, love, protect and improve the environment and Natural Resources,

...10. It aims to understand natural events, vitality in nature, diversity of vitality and their relations with each other."(MoNE, 1998d, p.314).

Two objectives in the Science curriculum are associated with Geography education. These consist of recognizing the environment and natural resources, and understanding natural events.

\section{Geographical Education in the Primary School Curriculum of 2005}

The 2005 Primary School Curriculum adopted a constructivist approach based on skills and focused on the student instead of the teacher. Looking at Table 7, it is seen that the courses which include topics related to geography education are Life Science, Science and Technology, and Social Studies. The duration of the Life Science course in Grades 1, 2 and 3 are 5 hours each; the duration of Science and Technology courses in Grades 4 and 5 are 4 hours each; and the duration of the Social Studies course in Grades 4 and 5 are set as 3 hours each.

Table 7

2005 Primary School Program Weekly Course Distribution Chart (MoNE, 14.07.2005d, 192 Resolution)

\begin{tabular}{|c|c|c|c|c|c|}
\hline Lessons & 1. grade & 2. grade & 3. grade & 4. grade & 5. grade \\
\hline Turkish & 12 & 12 & 12 & 6 & 6 \\
\hline Math & 4 & 4 & 4 & 4 & 4 \\
\hline Life Science & 5 & 5 & 5 & - & - \\
\hline Science & - & - & - & 4 & 4 \\
\hline Social Studies & - & - & - & 3 & 3 \\
\hline Foreign Language & - & - & - & 2 & 2 \\
\hline Religious culture and ethics & - & - & - & 2 & 2 \\
\hline Painting & 2 & 2 & 2 & 1 & 1 \\
\hline Music & 2 & 2 & 2 & 1 & 1 \\
\hline Physical Education & 2 & 2 & 2 & 1 & 1 \\
\hline Traffic and first aid & - & - & - & 1 & 1 \\
\hline $\begin{array}{lll}\text { Guidance } & \text { and } \\
\text { activities } & & \\
\end{array}$ & 1 & 1 & 1 & 1 & 1 \\
\hline Optional lessons & - & - & - & 3 & 3 \\
\hline
\end{tabular}

The general purposes of the 2005 Life Science course curriculum related to Geography were determined as follows:

$\checkmark$ “...A person at peace with himself, his social environment and nature, 
Yıldız Yllmaz, N., Meydan, A. (2020). Geographical Education in Primary School Curriculum in...

$\checkmark$... Recognizing, protecting and developing oneself, nation, homeland and nature..." (MoNE, 2005a, p.8).

In the curriculum of the Life Science course, two purposes are associated with geographical education, which consists of being at peace with nature and protecting nature.

The Social Studies curriculum was prepared in 2005. In this program, the general objectives of the Social Studies course related to Geography are as follows:

$\checkmark$ “...6. By recognizing the geographical features of the environment and the world in which it lives, it explains the interaction between humans and the natural environment ...." (MoNE, 2005b, p.9).

In the Social Studies course curriculum, one general purpose is associated with geography education. This aim consists in explaining the interaction between human and natural environment by knowing the geographical features.

The general purposes of geographical education included in the 2005 Science and Technology course curriculum are as follows:

$\checkmark$ "1. To enable them to learn and understand the natural world, to experience its intellectual richness and excitement," (MoNE,2005c, p.9)

The aim of one Science and Technology course in the curriculum is associated with geographical education, and this purpose is defined as learning about the natural world.

\section{Geographical Education in the Primary School Curriculum of 2018}

The 2018 primary school curriculum is based on student skills and competencies. Looking at Table 8, it is seen that the courses that include topics related to geographical education are Life Science, Science and Social Studies. In Grades 1, 2 and 3 by reducing the duration of the Life Science course the classes are each 4 hours; the duration of the Science course in Grades 3 and 4 are 3 hourseach; the duration of the Social Studies course in Grade 4 are set at 3 hours. In Table 8, the primary school was reduced to 4 years and the Science course was reduced to 3 hours. It seems that it is a course taught from the classroom.

Table 8

2018 Primary School Program Weekly Course Distribution Chart (MoNE, 2018a)

\begin{tabular}{lcccc}
\hline Lessons & 1. grade & 2. grade & 3. grade & 4. grade \\
\hline Turkish & 10 & 10 & 8 & 8 \\
\hline Math & 5 & 5 & 5 & 5 \\
\hline Life Science & 4 & 4 & 3 & - \\
\hline Science & - & - & 3 & 3 \\
\hline Social Studies & - & - & - & 3 \\
\hline Foreign Language & - & 2 & 2 & 2 \\
\hline Religious culture and ethics & - & - & - & 2 \\
\hline Painting & 1 & 1 & 1 & 1 \\
\hline Music & 1 & 1 & 1 & 1 \\
\hline Physical Education and play & 5 & 5 & 5 & 2 \\
\hline Traffic Safety & - & - & - & 1 \\
\hline Human rights, citizenship and & - & - & - & 2 \\
democracy & & & & \\
\hline
\end{tabular}


The general objectives of the 2018 life science course curriculum related to geography are as follows:

$\checkmark$ A person who recognizes himself and the environment in which lives,

$\checkmark$ Develops ability to use resources efficiently,

$\checkmark$ Be sensitive to nature and environment..." (MoNE, 2018b, p.8).

When the curriculum of the Life Science course was examined, it was determined that three purposes were associated with geographical education. These consist of recognizing the environment, using resources efficiently, and being sensitive to nature.

The general objectives of the 2018 Social Studies curriculum related to Geography are as follows:

$\checkmark$ “...5. By recognizing the general geographical features of the world with the environment in which it lives, they explain the interaction between the human and the environment and develop the ability to perceive place,

$\checkmark \quad$...6. They are aware of the limitations of the natural environment and resources and try to protect natural resources within the framework of environmental sensitivity and have a sustainable understanding of the environment, ...

$\checkmark$...17. Sensitivity to issues of concern to their country and the world..." (MoNE, 2018d, p.8).

In the curriculum of the Social Studies course, three achievements are associated with geographical education. These consist of gaining the ability to recognize geographical misses and perceive space, showing sensitivity to issues related to the use of natural resources and the country and the world.

From 2012 onwards the Science course started to be taught since the third grade The general objectives of the 2018 Science course curriculum related to Geography are as follows:

$\checkmark$ “...2. In the process of discovering nature and understanding the relationship between man and environment, adopting scientific process skills and scientific research approach and creating solutions to problems encountered in these areas,

$\checkmark 3$. Awareness of the interaction between the individual, environment and society; developing awareness of sustainable development related to society, economy and natural resources, ...

$\checkmark$ 7. Arouse interest and curiosity about events occurring in nature and its immediate surroundings, develop attitudes," (MoNE, 2018c, p.9).

When the Science curriculum was examined, it was determined that three objectives were associated with geographical education. These are determined in the form of discovery of nature, human-environment interaction, use of natural resources, and arousing curiosity about events in nature.

\section{Conclusion and Discussion}

Geographical education is a type of education that responds to the wishes of individuals to perceive the environment and place in which they live. For this reason, geographical education in all programs starting from 1924 Primary School Curriculum to 2018 Primary School Curriculum has taken its place in different courses or in curricula called Geography. It was determined that Geography courses 
were given 2 hours in 1924, 1926, 1936 and 1948, under the name of Geography, and were then abolished. It was determined that geography education had only two courses in the 1924 program, while in 1926 and later it had spread to the content of three courses. Due to the Life Science course originating with collective learning analysis, it was a course in which basic knowledge of Social Studies and Science was given. Social Studies course includes sub-disciplines such as Geography, History, and Anthropology. Science, on the other hand, includes sub-disciplines such as Physics, Chemistry, and Biology, and they is indirectly or directly associated with Geography. Although the names of the courses are different from this point of view, Geography subjects exist in school programs under the name of Life Science and Social Studies at the primary level; it is in Science, and Geography at the secondary level. A study conducted by Kızılçaoğlu (2006) was also not associated with the subjects of the Natural Sciences course geography. In addition, Taşlı (2000) and Engin, Akbaş, Gençtürk (2003) have linked Geography to general culture courses as a positive science that lies between Science and Social Sciences in terms of its subjects and plays a unifying role.

1924 the first school program is a continuation of the pre-Republic-era and was prepared as a stage of transition to the Republic-era. It is planned separately for male and female students. The main difference between the 1924 program, which includes 26 hours of lessons per week, and the pre-Republican programs, is that very few courses are added, changed, and some course topics are adapted to the Republican administration (Kapluhan, 2012). The content of the 1924 program was created within the framework of understanding nature and human life from a scientific point of view (Aslan, 2011). Therefore, in a nature-oriented program, it is inevitable that there will be information in the form of subject integrity associated with geographical education. When the 1924 program was examined, it was determined that the Geography course dealt with almost all subjects related to Geography, from where they lived to the poles, from the geographical features of Turkey, to their relations with their neighbors, in accordance with the integrity of the subject. In addition to geography education, natural examination, agriculture, hygiene courses are also topics related to geographical education in later programs, which appear when the purposes of this course are examined. In this program, the purposes of nature examination, agriculture, hygiene courses are examined because the purposes are not explained in the program.

When the 1926 Primary School Program was examined, it was determined that there were four purposes for the Geography course. In 1924, the first school program explained the issues in more detail with the integrity of the subject, while in 1926 it was determined that the targets were given directly and included 4 general statements. In addition, while the purposes related to the natural knowledge course were not explained in the 1924 Primary School Curriculum, the purposes of the natural knowledge course were determined in the 1926 Primary School Curriculum, and three of them were found to be related to geography education. One of the most important features of the 1926 Primary School Curriculum was the practice of collective teaching. According to this method, the courses in the first three classes were centered around the units in the life science course, and the program of each course was based on new and vibrant principles (Arslan, 2000). In 
the old curriculum (MoNE, 1924), the lessons of Nature study, History and Geography were shown separately, but in the new curriculum they were collected under the name of Life Science in the first circuit. Apart from these, for the first time in 1926, the purpose of the Geography course was included in the purposes of primary schools. It was underlined that local conditions should always be taken into account in the teaching of life knowledge, and the importance of observation in Geography issues was stated, and it was stated that special attention should be given to the subject of place and time in this observation (Kapluhan, 2012). In this direction, when the purposes of the Life Science course were examined in the program, it was determined that only two purposes were related to geographical education. It has been determined that these purposes coincide with the purposes of the Geography course and natural knowledge courses.

In the 1936 Primary School Curriculum, the purposes of the Geography course were determined more clearly and clearly, and indirectly the views of the republican period were also clearly stated. Due to the fact that geography subjects are not considered separate from the content of the life science course, there have been decreases in course hours (Kapluhan, 2012). In this program, the purposes of the geography course are increased to five. Map knowledge is one of the new skills in this program after the 1924 program. When the purposes of the geography course are examined, it is seen that the 1926 primary school curriculum has one more than the purposes. Two of the purposes of the Life Science course are associated with Geography education. But their content differs from each other. Three of the purposes of the natural knowledge course are related to geographical education and coincide with the 1926 program in both number and content.

The 1948 Primary School Curriculum was the last program in which geographical education existed under the name Geography. Life Science, Nature knowledge and Geography courses are those with subjects belonging to geographical education. The objectives of the Geography course in the program are exactly the same in terms of number and content as the previous program, the 1936 Primary School Curriculum. The purposes of the Life Science course associated with Geography are the same number as the previous program in number and three. But it's different from the inside. The purposes of the natural knowledge course associated with geographical education are four, which is one more than the previous program.

The 1968 Primary School Curriculum includes Life Sciences, Social Studies, and Science and Natural Sciences. In this study in Grades 4 and 5 under the name Social Studies and Science courses in the 1968 Primary School Curriculum, consolidation was implemented within the classes. In the program, four general objectives are defined for the Social Studies course, and only one of them is associated with geographical education. But there are five other sub-purposes below this purpose, and the purposes or purposes contained in previous programs are similar in terms of content. One general purpose of the Life Science course in the program is associated with geographical education, and there are four sub-purposes of this purpose. In addition, these sub-purposes are more defined as attitude-oriented purposes. Five objectives of the Science course are related to geographical education. $48 \%$ History, 30\% Civics and 22\% Geography were given emphasis in the 
Social Studies course program, therefore the least share was devoted to geography (Örs, 2007).

In the 1998 Primary Education Curriculum, the three objectives of the Life Science course were associated with geographical education. Compared to the 1968 primary school curriculum, geographical education given in the Life Science course is more extensive and detailed in the new curriculum (Ünlü, 2001). One general purpose of the Social Studies curriculum is associated with geographical education, while all seven sub-purposes of this general purpose are associated with geographical education. Unlike previous programs, the characteristics of the places where the Turkish people lived were determined as a purpose. The teaching objectives of the Science course are three more than the previous program, and the two objectives are associated with geographical education.

In the 2005 Primary School Curriculum, the total number of purposes for geographical education occurred in Life Science, Social Studies, Science and Technology courses, which is four. In the Life Science course, there are two purposes associated with Geography, while in the Social Studies course, and Science and Technology courses, there are only one purpose each. Compared to previous programs, geographical education is almost absent in this program. In the study conducted by Sağdıç (2020), it was stated that the programs prepared in 2005 and after were prepared with an interdisciplinary approach and within the framework of achievements. In the use of an interdisciplinary approach in programs, it has been important to take advantage of the interdisciplinary feature of geography.

A total of nine objectives were determined in the 2018 primary school curriculum, including three in the Life Sciences curriculum related to geographical education, three in the Social Studies curriculum and three in the Science curriculum. In the previous 2005 program, the general purposes of geographical education, which were significantly reduced, were again increased in this program. In addition, for the first time in the Social Studies curriculum, space perception was included in general purposes. In a study conducted by Sağdıç (2020), two objectives of the Social Studies curriculum were associated with geography education. These are "" ... 5. By recognizing the general geographical features of the world with the environment in which it lives, they explain the interaction between man and the environment and develop their ability to perceive space..." with "...17.Their sensitivity to issues that concern their country, and the world is determined as..." (MoNE, 2018d, p. 8). But unlike the Sağdıç (2020) study, this study "...6. Being aware of the limitations of the natural environment and resources and trying to protect natural resources in the context of environmental sensitivity and having a sustainable understanding of the environment," it is associated with geography education because the natural environment and the limitation of resources are included in the content of geographical education.

From primary school, the provision of geographical education to students is determined as an important point because it is important for students to know the environment, country and world in which they live, to live better in the present and future, to face fewer problems. As a matter of fact, Kızılçaoğlu (2006) notes that in his research, primary school students are geographically knowledgeable and that 
classroom teachers have important tasks in gaining the foundations of spatial and ecological perspectives from basic geographical points of view.

\section{Suggestions}

- Purposes related to geographical education have shown a decreasing momentum in general. It seems to be quite small, especially in recent programs. Therefore, the gains related to geographical education can be increased in the programs.

- The duration of these courses can be extended, given that the reason for reducing the purposes associated with geographical education is also a gradual decrease in duration.

- Since the general purposes related to geographical education will be achieved with the basic level of information given in the life Knowledge course, the purposes in the life Knowledge course can be increased to include all the basic information.

- Different dimensions of geographical education in primary school can be studied by field experts in order to contribute and improve the field.

\section{References}

Akınoğlu, 0. (2005). The Effectiveness of and problems in geography education. International Journal of Geography and Geography Education, (12), 77-96. Retrieved from https://dergipark.org.tr/en/pub/marucog/issue/459/3682

Arslan, M. (2000). Cumhuriyet dönemi ilköğretim programları ve belli bașlı özellikleri. Milli Ĕgitim Dergisi, 146, 42-48. Retrieved from http://dhgm.meb.gov.tr/Yayimlar /dergiler/Milli_Egitim_Dergisi/146/aslan.htm

Aslan, E. (2011). The First primary school curriculum of the Turkish Republic: "1924 Ilk Mektepler Müfredat Programı" Elementary Education Online, 10(2), 717-734, Retrieved from http://ilkogretim-online.org.tr/index.php/io/article/viewFile/ $1616 / 1453$

Bonnett, A. (2008). What is geography? London, Sage Publication. Retrieved from https://books.google.com.tr/books?hl=tr\&lr=\&id=G_491U8PQFEC\&oi=fnd\&pg=PP2 \&dq=what+is+geography\&ots=LUmlIxsjpC\&sig=JuBojQjMMasDzCHaCgkohQJrAns\&r edir_esc=y\#v=onepage $\& \mathrm{q}=$ what $\% 20$ is $\% 20$ geography $\& \mathrm{f}=$ false

Bowen, G. A. (2009). Document analysis as a qualitative research method. Qualitative research journal, 9(2), 27-40. Retrieved from https://www.researchgate.net/profile /GlennBowen/publication/240807798_Document_Analysis_as_a_Qualitative_Resear ch_Method/links/59d807d0a6fdcc2aad065377/Document-Analysis-as-aQualitative-Research-Method.pdf

Daşcan, Ö. (2018). 2018 İlkokul programı 1-4 sınıflar. Ankara, Anı Yayıncılık.

Doğanay, H. (1998). Coğrafyaya giriş. Konya, Çizgi Kitabevi

Engin, İ., Akbaş, Y., \& Gençtürk, E. (2003). I. Coğrafya kongresinden günümüze liselerimizde müfredat programlarındaki değişimler. Milli Eğitim Dergisi, 157, 103-114. Retrieved fromhttp://dhgm.meb.gov.tr/yayimlar/dergiler/milli_egitim_dergisi/157/ergin.htm

Erinç, S. (2000). Jeomorfoloji I. İstanbul, Der yayınları. 
İlhan Beyaztaş, D., Kaptı, S. B. \& Senemoğlu, N. (2013). An Analysis of elementary school curricula since the foundation of Republic of Turkey. Ankara University, Journal of Faculty of Educational Sciences, 46(2), 319-344. Retrieved from https://doi.org/10.1501/Egifak_0000001308

Kapluhan, E. (2012). Atatürk period (1923-1938) of geography education in primary school. International Journal of Geography and Geography Education, 25, 152-170. Retrieved from http://dspace.marmara.edu.tr/xmlui/bitstream/handle/11424 /2658/ 704-1367-1-SM.pdf?sequence=1\&isAllowed=y

Karasar, N. (2011). Bilimsel araştırma yöntemi. Ankara, Nobel Yayıncılık.

Kızılçaoğlu, A. (2006). Geographic education in elementary schools. International Journal of Geography and Geography Education, 14, 81-106. Retrieved from http://dspace.marmara.edu.tr/xmlui/bitstream/handle/11424/2505/544-1045-1SM.pdf?sequence $=1 \&$ isAllowed $=y$

The Ministry of Culture (1936). İlkokul programı. İstanbul, Devlet Basımevi

Ministry of Education (1924). İlk mekteplerin müfredat programı. İstanbul, Matbaa-i Amire.

Ministry of Education (1926). İlk mekteplerin müfredat programı. İstanbul, Millî Matbaa

Maxwell, J. (1992). Understanding and validity in qualitative research. Harvard Educational Review, 62(3), 279-301. Retrieved from http://www.msuedtechsandbox.com /hybridphd/wp-content/uploads/2010/06/maxwell92.pdf

Meydan, A. (2017). Coğrafya nedir? In Hakkı Yazıcı \& Nusret Koca (Eds.). Genel Coğrafya (8. Edition), pp. 1-20, Ankara, Pegem Akademi Yayıncllı.

Ministry of National Education. (1948). İlkokul programı. İstanbul, Milli Eğitim Basımevi.

Ministry of National Education. (1968). İlkokul programı. İstanbul, Milli Eğitim Basımevi.

Ministry of National Education. (1998a). İlköğretim okulu haftalık ders çizelgesi. Milli Ĕ̆itim Bakanlığı Tebliğler Dergisi, 61(2492), 1012. Retrieved from http://tebligler.meb.gov.tr/index.php/tuem-sayilar/finish/62-1998/315-2492eylul-1-1998

Ministry of National Education. (1998b). İlköğretim okulu hayat bilgisi programı. Milli Ĕ̆itim Bakanlı̆̆ı Tebliğler Dergisi, 61(2484), 5-120. Retrieved from http://tebligler.meb.gov.tr/index.php/tuem-sayilar/finish/62-1998/304-2484ocak1998

Ministry of National Education. (1998c). İlköğretim okulu sosyal bilgiler dersi öğretim programı. Milli Eğitim Bakanlığı Tebliğler Dergisi, 61(2487), 531-568. Retrieved from http://tebligler.meb.gov.tr/index.php/tuem-sayilar/finish/62-1998/308-2487nisan-1998

Ministry of National Education. (1998d). İlköğretim okulu fen bilgisi programı. Milli Ĕgitim Bakanlığı Tebliğler Dergisi, 61(2484), 130-198. Retrieved from http://tebligler.meb.gov.tr/index.php/tuem-sayilar/finish/62-1998/304-2484ocak1998

Ministry of National Education. (2005a). İlköğretim hayat bilgisi dersi öğretim programı. Ankara, Devlet Kitapları Müdürlüğü.

Ministry of National Education. (2005b). İlköğretim sosyal bilgiler dersi öğretim programı. Ankara, Devlet Kitapları Müdürlügü.

Ministry of National Education. (2005c). İlköğretim fen ve teknoloji dersi öğretim programı. Ankara, Devlet Kitapları Müdürlügü. 
Ministry of National Education. (2005d). İlköğretim okulu haftalık ders çizelgesi. Tebliğler Dergisi, 2575, s. 539, Retrieved from http://tebligler.meb.gov.tr/index.php/tuemsayilar/finish/69-2005/195-2575-agustos-2005

Ministry of National Education. (2018a). İlköğretim Kurumlari (İlkokul Ve Ortaokul) Haftalik Ders Çizelgesi. T.C. Milli Eğitim Bakanlığı. Retrieved from http://ttkb.meb.gov.tr/meb_iys_dosyalar/2018_10/08141710_ilkogretimkurumlari _hdc.rar

Ministry of National Education. (2018b). Hayat Bilgisi Dersi Öğretim Programı (İlkokul 1, 2 ve 3. Sinıflar). T.C. Milli Eğitim Bakanlığı. Retrieved from http://mufredat.meb.gov.tr/ProgramDetay.aspx?PID=326

Ministry of National Education. (2018c). Fen Bilimleri Dersi Öğretim Programı (İlkokul ve Ortaokul 3, 4, 5, 6, 7 ve 8. Sinıflar). T.C. Milli Eğitim Bakanlığı. Retrieved from http://mufredat.meb.gov.tr/ProgramDetay.aspx?PID=325

Ministry of National Education. (2018d). Sosyal Bilgiler Dersi Öğretim Programı (İlkokul ve Ortaokul 4, 5, 6 ve 7. Sinıflar). T.C. Milli Eğitim Bakanlığı. Retrieved from http://mufredat.meb.gov.tr/ProgramDetay.aspx?PID=354

Ministry of National Education. (2018e). Ortaöğretim Coğrafya Dersi (9, 10, 11 ve 12. Sınıflar) Öğretim Programı. T.C. Milli Eğitim Bakanlığı. Retrieved from http://mufredat.meb.gov.tr/Dosyalar/2018120203724482-

Cografya\%20dop\%20pdf.pdf

Örs, H., (2007). İlköğretim Okullarında 6. Sınıf Sosyal Bilgiler Dersi Coğrafya Konularının Program Yönünden İncelenmesi, Adnan Menderes Üniversitesi, Sosyal Bilimler Enstitüsü, Unpublished master thesis, Aydın. Retrieved from http://adudspace.adu.edu.tr:8080/xmlui/bitstream/handle/11607/201/hakan_ors _tez.pdf.pdf?sequence=3\&isAllowed=y

Özdemir, T. (1997). Coğrafya terimine etimolojik bir yaklaşım ve ötesi. Eastern Geographical Review, 2, 219-226. Retrieved from https://dergipark.org.tr/tr/download/articlefile/26755

Özçağlar, A. (2000). Coğrafyaya giriş. Ankara, Hilmi Usta Matbaacllık.

Pinar, A., \& Tuncer, T. (2019). A Potential outdoor laboratory in geography education: Bolluk Lake and its environment. Future Visions Journal, 3(3), 24-40. DOI: 10.29345/futvis.72

Roberts, P. \& Priest, H., Traynor, M. (2006). Reliability and validity in research. Nursing Standard, 20, 41-45. Retrieved from https://www.researchgate.net/publication /306332255_Reliability_and_validity_in_research

Sağdıç, M. (2020). Historical development of geography teaching in elementary schools in Turkey. International Journal of Turkish Literature Culture Education, 9(1), 395-412. Retrieved from https://dergipark.org.tr/en/download/article-file/1025468

Sönmez, V. \& Alacapınar, G. A. (2016). Örneklendirilmiş bilimsel araştırma yöntemleri. Ankara, Anı Yayıncilık.

Taşlı, İ. (2000). Günümüz coğrafya öğretiminde öğrenci aktivitelerinin bilgi üretimine dönüştürülmesinde olgular, kavramlar ve genellemelerin sistematik kullanımının sağlanması. Milli Eğitim Dergisi, 145, 31-33. Retrieved from http://dhgm.meb.gov.tr/yayimlar/dergiler/Milli_Egitim_Dergisi/145/tasli.htm

Ünlü, M. (2001). The Geography education and teaching in of primary school. International Journal of Geography and Geography Education, 3 (2), 31-48. Retrieved from 
Yıldız Yllmaz, N., Meydan, A. (2020). Geographical Education in Primary School Curriculum in...

http://dspace.marmara.edu.tr/bitstream/handle/11424/2425/444-853-1SM.pdf? sequence $=1 \&$ isAllowed $=\mathrm{y}$

Yıldırım, A. \& Șimşek, H. (2018). Sosyal bilimlerde nitel araştırma yöntemleri. Ankara, Seçkin Yayıncilı.

\section{Biographical Statements}

Nihal YILDIZ YILMAZ completed her undergraduate degree in 2006 at Selçuk University, Faculty of Education, Department of Primary Education. In 2015, She completed her Ph.D. in Necmettin Erbakan University. She worked as a classroom teacher in the Ministry of National Education between 2006-2009. he worked as a doctor lecturer in Karamanoğlu Mehmetbey University, Faculty of Education between 2015-2020. She continues to work at the same university by taking the title of associate professor in 2020. Fields of study: Primary education, Social studies education, nature education.

Ali MEYDAN is a full professor and the dean of the faculty of education in Nevsehir Hacl Bektas University, Turkey. He graduated from Selçuk University, Faculty of Education in 1997. Dr. Meydan was appointed as a research assistant to the Faculty of Education at Selcuk University in 1998 and completed his master's degree in 2000 and his $\mathrm{PhD}$ in 2004. He worked at Mersin University between 2009 and 2012. He has been working at Nevşehir Hacı Bektaş Veli University since 2012. He has articles in various scientific journals, national and international symposiums and publications. Fields of study: Geography education, Social studies education, nature education. 